\title{
Rate of Exposure to Violence in 112 Staff in Denizli City
}

\author{
Atakan Yılmaz', Onur Dal', Serpil Yaylacı ${ }^{3}$, Emrah Uyanık \\ 'Emergency Service, Tekirdağ State Hospital, Tekirdağ, Turkey \\ 2Department of Emergency Medicine, Adnan Menderes University Faculty of Medicine, Aydın, Turkey \\ ${ }^{3}$ Depatment of Emergency Medicine, Acıbadem University Faculty of Medicine, İstanbul, Turkey
}

\begin{abstract}
Aim: In the last decade, news regarding violence of the 112 emergency service staff that is frequently revealed in visual and written media in our country has increased. In this study, we investigated the characteristics that led to the incidence of violence against the 112 emergency service staff, the extent to which these events have been reported by staff, and the work satisfaction of staff.
\end{abstract}

Materials and Methods: Data regarding face-to-face interviews with all staff on duty across the city were obtained. Staff who suffered verbal and physical violence in the last year and during their work period were examnined. Staff who did not wish to participate in the study, who served in the 112 emergency service for less than one year, and who were on an annual leave or leave without pay during the study were excluded.

Results: One hundred and forty-one eligible staff participated in this study. Of the total participants, $73 \%$ ( $n=103)$ were emergency medical technicians and paramedics. The average work period in the 112 emergency medical services was $4.9 \pm 2.8$ (min: 1, max: 23) years. The staff's exposure to verbal and physical violence over the last year was $51.8 \%(n=73)$ and $8.5 \%(n=12)$, respectively. Rates increased by $77.3 \%(n=109)$ and $24.8 \%(n=35)$, respectively, when investigation was conducted in the absence of time limitation. Of the total participants, $85.1 \%(n=120)$ were found to not formally report the attacks. A large percentage (95.2\%) of reported incidents involved physical violence. Finally, the participants levels of work satisfaction in the 112 emergency service was high (90.8\%, $\mathrm{n}=128)$.

Conclusion: Violence against the 112 emergency service staff is greater than estimated because there were not sufficiently reported. Trainings must be organized for staff working in prehospital medical care regarding how to protect and cope from violence. (Eurasian J Emerg Med 2015; 14: 103-6)

Keywords: Prehospital, ambulance, workplace, violence

\section{Introduction}

Under the command of the provincial ambulance service founded within the emergency healthcare service branch of the city's health administration, 112 provincial healthcare service is defined as all the healthcare services provided by the well-trained teams either at the scene of accident or during the transfer through completely equipped ambulances and medical outfit support in the event of illnesses and injury as well as extraordinary incidents (1). In recent years, the acts of violence aimed at the 112 staff have often hit the headlines in both visual and written media in our country. The fact that the incidence of these attacks on emergency staff, who immediately arrive at the scene to save the life of a citizen, work diligently during $7 / 24$, and sometimes risk their own lives for the sake of others, is on the increase, is actually worrisome $(2,3)$. According to the joint report titled "Violence at the Workplace in Healthcare Sector" by World Health Organization and International Labour Organization, the majority of all the acts of violence occur in the health sector (4). This study tries to gain an insight in the characteristics of the acts of violence to which 112 staff working in Denizli Province are exposed, to what extent these incidents are reported by them, and their job satisfaction.

Correspondence to: Emrah Uyanık e-mail: emrah_uyanik@hotmail.com

Received: 27.11.2013 Accepted: 18.01.2014

oCopyright 2015 by Emergency Physicians Association of Turkey - Available online at www.eajem.com DOI: $10.5152 /$ eajem.2015.90958 


\section{Materials and Methods}

After the written approval had been granted for the study by the Denizli City Health Administration, a list was made for all the 112 staff employed in the Denizli province. The staff were individually interviewed and informed about the study in their off time. It was pointed out as to why the study was being conducted and that the Denizli City Health Administration had approved of the study. Furthermore, they were assured that the data to be obtained from the study would not pose a threat to themselves. Those who did not wish to participate in the study, who worked for 112 under one year, and who took an annual leave or left without pay during the study were not included.

The verbal and physical violence to which the participating staff had been exposed, both in the last year and during the whole employment period, was thoroughly investigated. Prior to the interview, the definition of verbal and physical violence and their examples were explained to the participants. The last but not the least, they were asked whether they were satisfied with working for the 112 .

\section{Statistical analysis}

All the data obtained from the study was saved and evaluated with the standard program, called "Statistical Package for Social Sciences (SPSS Inc., Chicago, IL, USA) for Windows 14." Numerical variables were summarized as mean $\pm \mathrm{SD}$, whereas categorical variables were summarized as numbers and percentage.

\section{Results}

The study comprised 141 (71.2\%) out of the 198 inidividuals working for Denizli 112 emergency service. In this study, 57 employees were excluded (on the grounds that 40 took annual leave, 11 did not wish to participate, and six worked under one year).

The average age for the 112 staff participating in this study was $30.3 \pm 9.2$ years. The ratio of men and women was close to each other [50.4\% women $(n=71), 49.6 \%$ men $(n=70)]$. The average working period of the participants in the 112 emergency service were obtained as $4.9 \pm 2.8$ ( $\min : 1$ max: 23 ) years. The duty breakdown of the staff is illustrated in Table 1. In our study, the largest group comprised emergency medical technicians (EMT) ( $n=67,47.5 \%)$

The participants were asked, "Have you ever been exposed to verbal or physical attacks by patients or their relatives while working?" The rates of the staff for being exposed to verbal and physical violence in the last year were $51.8 \%(n=73)$ and $8.5 \%(n=12)$, respectively. When the same question was asked with respect to "throughout

Table 1. The duty breakdown of the staff

\begin{tabular}{|l|c|c|}
\hline Duty & $\mathbf{n}$ & \% \\
\hline Physician & 7 & 5.0 \\
\hline Nurse & 1 & 0.7 \\
\hline Paramedic & 36 & 25.5 \\
\hline EMT & 67 & 47.5 \\
\hline Driver & 21 & 14.9 \\
\hline Other & 9 & 6.4 \\
\hline Total & 141 & 100.0 \\
\hline EMT: Emergency &
\end{tabular}

EMT: Emergency Medical Technicians their working years in 112," the rates increased to $77.3 \%(n=109)$ and $24.8 \%(n=35)$, respectively. The participants' answers were provided in Table 2. Out of the 35 staff members reporting that they were subjected to a physical attack while working, 17 (48.6\%) of them turned out to be EMTs, 13 (37.1\%) paramedics, three (8.6\%) drivers, and two $(5.7 \%)$ physicians. With respect to gender, $77.1 \%(n=27)$ of them were male; furthermore, $58.7 \%(n=64)$ of those reporting that they were exposed to verbal violence while working were male.

The partcipants' answers to the question "Have you ever reported any kind of (verbal or physical) attack aimed at you while working for 112 ?" were analyzed. It was revealed that $85.1 \%(n=120)$ of the participants had not officially reported these attacks at all (Table 3 ). Furthermore, it was demonstrated that 20 (95.2\%) out of the 21 individuals who informed that they had reported the case were subjected to physical violence during the event.

Table 2. The rates of verbal and physical attacks that the staff reported to have experienced

\begin{tabular}{|l|c|c|}
\hline Verbal attack & $\mathbf{n}$ & \% \\
\hline In the last year & & 48.2 \\
\hline Never & 68 & 18.5 \\
\hline Once & 26 & 26.2 \\
\hline Twice or three times & 10 & 7.1 \\
\hline More than three times & & \\
\hline Throughout career & 32 & 22.7 \\
\hline Never & 6 & 4.3 \\
\hline Once & 25 & 17.7 \\
\hline Twice or three times & 78 & 55.3 \\
\hline More than three times & $\mathbf{n}$ & $\%$ \\
\hline Physical attack & & \\
\hline In the last year & 129 & 91.5 \\
\hline Never & 8 & 5.7 \\
\hline Once & 4 & 2.8 \\
\hline Twice or three times & 0 & 0 \\
\hline More than three times & 106.5 \\
\hline Throughout career & & \\
\hline Never & & \\
\hline Once & & \\
\hline Twice or three times & & \\
\hline More than three times & 12 & \\
\hline
\end{tabular}

Table 3. The rates of participants reporting the attacks

\begin{tabular}{|l|c|c|}
\hline Reporting & $\mathbf{n}$ & \% \\
\hline Never & 120 & 85.1 \\
\hline Once & 13 & 9.3 \\
\hline Twice or three times & 4 & 2.8 \\
\hline More than three times & 4 & 2.8 \\
\hline Total & 141 & 100.0 \\
\hline
\end{tabular}


Moreover, the study questioned whether the 112 staff was exposed to any verbal reaction from the public because of arriving at the scene late or for a similar reason. The rate of staff who had never experienced such verbal reaction was $36.9 \%(n=52)$. The exposure frequency to such reaction was found to be $63.1 \%(n=89)$ [once $7.1 \%$ $(n=10)$, twice or three times $20.5 \%(n=29)$, and more than three times $35.5 \%(n=50)]$.

The last but not the least, whether the participants are satisfied with working for 112 or not was investigated. It was determined that the participants are overwhelmingly $(90.8 \%, n=128)$ satisfied with working for 112. The obtained answers are provided in Table 4.

\section{Discussion}

This study investigated the acts of violence to which 112 staff working in Denizli, one of the largest and developed cities in Aegean region, Turkey, had been subjected. As a result, it was revealed that the acts of violence to which the staff was exposed were high (rate of verbal violence, $77.3 \%$; rate of physical violence, $24.8 \%$ ), yet such incidents were not reported most of the time.

There is actually little data regarding the ambulance staff's exposure to violence in our country. When we take a broader look at the phenomenon, it can be pointed out that the acts of violence aimed at healthcare workers in our country have been on the agenda in the past three years. The rise in the current events is also reflected in the agenda of the Parliament, and as a deterrent precaution, it was legalized that those who verbally and physically harass healthcare staff while they excercise their duties are heard before the law court on the basis of the crime "deliberately injuring a public official" (5).

A survey conducted by a health union regarding healthcare workers throughout Turkey demonstrates that the incidence of violence is higher in the Marmara region and south-eastern region. According to the survey, Aegean region is among the regions that have the least violence rate (6). In contrast, the results of our study, which we conducted regarding the 112 staff, advocate the fact that the acts violence do not differentiate between geographical regions.

The acts of violence aimed at healthcare workers have turned out to be a major problem not only in our country but also in the world at large in recent years. As in our own country, the victims of violent acts elsewhere are often the emergency and ambulance personnels (7). In 2011, a study conducted in Iran reports that the rate of pre-hospital healthcare personnel being exposed to verbal violence is $71 \%$ and that of physical violence is $38 \%$ as well as $9 \%$ being subjected to cultural harassment (8). In our study, the rate of exposure to verbal violence in the last year was $51.8 \%$ and that of physical violence was $8.5 \%$. The type of violence may be at different rates for different countries. It is essential that, depending on its own dynamics, each country should develop approaches to manage the problem at issue.

Table 4. The rates of the participants' satisfaction with their job in 112

\begin{tabular}{|l|c|c|}
\hline Satisfaction & $\mathbf{n}$ & \% \\
\hline Very happy & 45 & 31.9 \\
\hline Happy & 83 & 58.9 \\
\hline Not happy & 12 & 8.5 \\
\hline Not happy at all & 1 & 0.7 \\
\hline Total & 141 & 100.0 \\
\hline
\end{tabular}

Another prominent result of our study is that only a small number of violent acts are reported. Our study reveals that the $85.1 \%$ of the participants did not report therir exposure to violence, which is in fact very high. The rareness of the reported incidents is consistent with the literature (9). According to the studies focusing on this issue, it is predicted that as the healthcare staff become more aware, the violence will be recognized more, and it will be reported more and thus, the real rates will be obtained $(9,10)$.

According to a study conducted in our country, although the exposure to violence, which is regarded as "a natural side of their job" by the ambulance staff, is reported less freqently than what happens in reality, it is stated that being subjected to violent acts turns out to be the primary cause of stress, giving rise to negative emotions, such as high levels of anger and anxiety. In a study conducted in a large metropolis as California, the presence of the police at the scene, the presence of gangstas, psychiatric diseases, and alcohol and substance abuse are cited as the risk factors increasing the violent attitudes towards ambulance staff (11). It is recommed that emergency healthcare personnel should be offered counseling programs to recognize factors causing job stress, determine the effective ways to deal with stress and solve them, improve communication skills, and develop self-confident attitudes (10). What is more, healthcare staff must be encouraged and informed regarding reporting cases.

In international studies, as in our study, paramedics and EMTs often appear to be exposed to violence among the pre-hospital personnel too $(11,12)$. Koritsas et al. (12) reported that the professional skills of a paramedic, his receiving the call on the phone, and his weekly contact hours with the patients are actually risk factors in the exposure to verbal violence. Furthermore, convenient working hours and maintaining their frequency are suggested as a precautionary action to reduce the ambulance staff's potential of being exposed to violence. Other studies lay emphasis on the fact that healthcare personnel should be trained on how to avoid violence and cope with it so that they can manage the problem more efficiently by practicing the pre-arranged protocols $(9,10)$.

A systematic study conducted in our country reports that the healthcare staff being exposed to physical violence is often male, whereas female staff is exposed to verbal violece more than males (13). In contrast, we determined in our study, in which the ratio of males to females is equal, that male 112 staff are more often subjected to both violence types. This result can be accounted for by the fact that the rate of male employees in the pre-hospital healthcare staff in our country is mostly higher than the hospital staff.

\section{Study limitations}

This study did not gain an insight to the extent of the trauma in the acts of violence to which 112 staff was exposed. Besides, how the legal process worked in the reported cases and their consequences were not within the scope of this study.

\section{Conclusion}

Because the violence that 112 personnel experience in our country is not adequately and properly reported, it is indeed more than what is anticipated. Paramedics and EMTs are the ambulance staff who are subjected to such violence the most. The factors contributing to the existence of such violence and the sociocultural reasons that influence its presence should be presented through extensive studies in our country. In the light of the data obtained from this 
study, the 112 staff should undergo a standard training program on violence, while precautionary measures should also be introduced to minimize the violence.

Peer-review: Externally peer-reviewed.

Conflict of Interest: No conflict of interest was declared by the authors.

Financial Disclosure: The authors declared that this study has received no financial support.

\section{References}

1. Oktay I, Kayışoğlu N. Tekirdağ ili 112 acil sağlık hizmetlerinin değerlendirilmesi. Sürekli Tıp Eğitim Dergisi 2005; 14: 35-7.

2. ATT Der. web sitesi. Ulaşım adresi: http://www.attder.org.tr/van-112-personeline-yapilan-cirkin-saldiriyi-siddetle-kiniyoruz/ Ulaşım tarihi: 22 Ekim 2013.

3. Yıldırım A, Yıldırım D. Mobbing behaviors encountered by health science faculties staff and their responses to them. Turkiye Klinikleri J Med Sci 2010; 30: 559-70. [CrossRef]

4. Annagür B. Sağlık çalışanlarına yönelik şiddet: risk faktörleri, etkileri, değerlendirilmesi ve önlenmesi. Psikiyatride Güncel Yaklaşımlar 2010; 2: 161-73.
5. Büyükbayram $A, O k c ̧ a y ~ H$. The socio-cultural factors that affect violence in health care personnel. Journal of Psychiatric Nursing 2013; 4: 46-53. [CrossRef]

6. 112 acilservis web sitesi. Sağlıkta şiddetin haritası. Ulaşım adresi: http:// www.112acilservis.net/index.html. Ulaşım tarihi: 22 Ekim 2013.

7. Yıldırım HH. Sağlık iş yeri ortamında şiddet: Halkın şiddet algısı ve değerlendirmeleri. Ankara. 2011. p. 4.

8. Rahmani A, Hassankhani H, Mills J, Dadashzadeh A. Exposure of Iranian emergency medical technicians to workplace violence: a cross-sectional analysis. Emerg Med Australas 2012; 24: 105-10. [CrossRef]

9. Pozzi C. Exposure of prehospital providers to violence and abuse. J Emerg Nurs 1998; 24: 320-3. [CrossRef]

10. Canbaz S, Dündar C, Dabak S, Sünter AT, Pekşen Y, Cetinoğlu EC. Violence towards workers in hospital emergency services and in emergency medical care units in Samsun: an epidemiological study. Ulus Travma Acil Cerrahi Derg 2008; 14: 239-44.

11. Grange JT, Corbett SW. Violence against emergency medical services personnel. Prehosp Emerg Care 2002; 6: 186-90. [CrossRef]

12. Koritsas $S$, Boyle $M$, Coles J. Factors associated with workplace violence in paramedics. Prehosp Disaster Med 2009; 24: 417-21. [CrossRef]

13. Ozcan NK, Bilgin H. Violence towards healthcare workers in Turkey: A systematic review. Turkiye Klinikleri J Med Sci 2011; 31: 1442-56. [CrossRef] 